Kasperowicz-Stępień A. (2015). The fiscal challenges of Polish integration with the euro area. Copernican Journal of Finance \& Accounting, 4(1), 83-96.http://dx.doi.org/10.12775/CJFA.2015.006

\author{
Alicja Kasperowicz-Stępień* \\ Finance Department, Cracow University of Economics
}

\title{
THE FISCAL CHALLENGES OF POLISH INTEGRATION WITH THE EURO AREA
}

Keywords: euro area, convergence criteria, fiscal policy, deficit, public revenue, public expenditure.

\section{J E L Classification: H3.}

Abstract: In May 2004, Poland became a member of the Economic and Monetary Union on the rights of the State with a derogation. This means that Poland is obliged to meet the convergence criteria in terms of fiscal and monetary policies and the introduction of the euro.

The aim of the articles is to show the need to take necessary action in the development of public revenue and expenditure for the implementation of the fiscal requirements of the European Union. The study used the following test method:

- analysis of the literature on the subject,

- analysis of normative acts,

- analysis of statistical data.

Translated by Alicja Kasperowicz-Stępień

\section{IIIINTODUCTION}

In May 2004, Poland became a member of the Economic and Monetary Union on the rights of the State with a derogation. This means that Poland is obliged to

Date of submission: April 7, 2014; date of acceptance: May 10, 2015.

* Contact information: kasperoa@uek.krakow.pl, Cracow University of Economics, Rakowicka 27, 31-510 Cracow, Poland, phone: +48 122935289. 
meet the convergence criteria in terms of fiscal and monetary policies and the introduction of the euro. The adoption of a single currency implies permanent stiffening of the zloty against the euro and the resignation of the ability to pursue independent monetary policy (Kasperowicz - Stępień 2011, 108-109). The current strategy of Polish integration with the euro zone, defined by the Council of Ministers, provides such economic policy orientation, which will guarantee the permanent fulfillment of the convergence criteria, in particular regarding fiscal discipline and taking additional steps to strengthen the potential of the Polish economy, including in the area of institutional. It is expected that the entry into the euro area will be an opportunity for the scenario of accelerated economic growth and growing wealth. However, the experience of the countries of the euro area, especially during the recent crisis, indicate that the euro is associated with an increased risk of macroeconomic instability and slow economic growth, especially in the case of countries with weak macroeconomic fundamentals.

Thus, the most important internal factor, i.e. dependent on national economic policy, is the degree of preparation of the Polish economy to become part of the common currency area. It is advisable that the decision to join the euro zone was preceded by a right reform program, leading to the strengthening of the foundations of Polish economy and bring them to the circumstances related to the functioning of the monetary union.

The aim of the articles is to show the need to take necessary action in the development of public revenue and expenditure for the implementation of the fiscal requirements of the European Union.

\section{RESEARCH METHODOLOGY}

The study used the following test method:

- analysis of the literature on the subject,

- analysis of normative acts,

- analysis of statistical data.

\section{THE CURRENT RULES FOR THE CONDUCT OF FISCAL POLICY IN THE EURO AREA}

EMU was founded as a monetary union, in which fiscal policy is decentralized (Borsi, Metiu 2013). In order to reduce the risks associated with maintaining a decentralized fiscal policy, in terms of monetary union it was necessary to 
introduce a common fiscal rules and procedures for their enforcement. (Hallerberg, Strauch, von Hagen 2007, 338-359; Vamvakidis 2008; Oręziak 2004, 43-92). The crisis has highlighted, however, that the adopted mechanisms for oversight of national fiscal policies were not effective enough, to prevent over-indebtedness by member states and ensure that national policies fiscal will be an effective tool for stabilizing the business cycle. Under the influence of the crisis has been decided to reform the supervision and coordination of fiscal policy in the EU (Houben, Kakes 2013).

In December of 2011 entered into force a package of six legislative acts in the field of strengthening economic governance, the so-called six-pack. And in May 2013 took effect double-pack. The new system of rules has been further strengthened by the fiscal pact (cf. The Treaty on Stability, Coordination and Management in EMU, TSCG), which entered into force in January 2013. It should be emphasized, that the main weaknesses of the Stability and Growth Pact (SGP) which were revealed by the debt crisis include (Ekonomiczne wyzwania 2014, 8-9; Fiscal compact signed 2012; Wyplosz 2013):

1. Improper design of fiscal rules, the politicization of their use and inadequate identification of the national authorities with the European rules. (Owsiak 2005, 786-789, Kasperowicz-Stępień 2013, 65-77, Ochrymiuk 2010).

2. The weakness of the statistical base European fiscal rules.

3. Inadequate consideration macroeconomic conditions in the activities of European fiscal rules.

The most important changes aimed at eliminating weaknesses model of surveillance and coordination of fiscal policies of euro area countries, including the weakness of the SGP, include (Ekonomiczne wyzwania 2014, 9-11):

I. Improvement of the construction and introduction of new European fiscal rules in order to increase the likelihood that the application of these rules will limit the risk to the solvency of the country and will result in a counter-cyclical fiscal policy. To this end:

1) increased emphasis on compliance with the criterion of public debt through the introduction of rules concerning the pace of its reduction in the country in which the ratio of public debt to GDP exceeds $60 \%$. With made operationalization of the debt criterion can be treated on a par with the deficit criterion in decisions regarding the excessive deficit procedure; 
2) on the application and evaluation of compliance with the fiscal rules by Member States was placed greater emphasis on fiscal effort in structural terms:

- To ensure, that countries will be maintained structural balance at the level of the the medium-term budgetory objective (MTO) or quickly sought to that level, introduced a new rule for public spending, according to which their growth rate should not exceed the growth of potential GDP (provided that the increase in expenditure is not accompanied by the introduction of additional instruments to increase revenue). This rule should allow the use of revenue windfalls (resulting from the cyclical upturn) on the reduction of debt, rather than on the sustainable growth of spending. This should limit the risks associated with the fiscal consequences of rising macroeconomic imbalances. To strengthen the role of structural variables in the assessment of the fiscal position of the country, introduced a quantitative definition of derogation from the MTO and the adjustment path in the event of the emergence of derogation from MTO.

Through its solutions disciplining fiscal policy is to take place over the economic cycle, and not just in a situation where the current deficit exceeds 3\% of GDP (Stefański 2008).

II. The introduction of solutions, that are supposed to enhance the enforceability of the fiscal rules of the European institutions and to limit the scale of the politicization of the application of these rules. These solutions include: 1) additional (compared to the already foreseen in the Treaty - Art. 126, paragraph. 11) financial sanctions;

2) the new voting system (reverse qualified majority), which increases automaticity and thus reduces the politicization of decision-making process regarding the imposition of sanctions: Commission recommendation for a financial sanction is considered approved unless it is rejected by the Council by qualified majority.

III. The introduction of solutions to increase the role of fiscal rules in the fiscal policy of the Member States, including solutions that aim to increase the identification of the authorities of the Member States with introduced fiscal rules at EU level and improve the enforceability of those rules.

IV. Strengthening of the coordination of fiscal and economic policy (including the role of the European Commission in the process) (Ministerstwo Finansów 2014; Wernik 2014, 144-149): 
1. Through the introduction of the European Semester, it is synchronized deadlines for the submission to the European Commission the national reform programs (including plans for structural reforms) and stability programs and assessments of the Member States in the field of economic and fiscal policy.

2. According to the two-pack, the common budgetary timetable was introduced for member states. They were required to submit to Commission budget plans for the next year to 15 October. Commission - in case of a serious breach of the obligations arising from SGP- may apply to the Member State concerned to submit a revised proposal.

3. Strengthened monitoring and supervision of the countries covered by the European Commission of the excessive deficit procedure, countries threatened with serious difficulties with regard to financial stability or receiving support from the ESM (mainly by increasing disclosure requirements and granting the Commission of privileges to draw up proposals for corrective action).

V. The introduction of solutions aimed at improving the statistical basis of European rules by the extending the competence of Eurostat, increasing the independence of national statistical offices and the introduction of financial sanctions for manipulation of statistics on deficit and public debt. Despite the extensive changes, essential model for creating and disciplining fiscal policy in the euro area remains unchanged.

\section{FISCAL POLICY IN THE CONTEXT OF POLISH ACCESSION TO EMU}

The 2008 global financial crisis and the Eurozone crisis have had significant negative influence on Poland's budget deficit and public debt (Sektor finansów 2011, 25-73; Ciak 2012, 218-219). Although Polish economy continued to grow, over the period 2008-2013 fiscal deficit was higher than the reference value (Table 1, Figure 2). Taking into account the prospect of Poland adopting the euro, this constitutes a considerable blow to Poland's ability to meet the fiscal convergence criteria (Kryzys finansów 2013, 11-37, Wieloletni plan 2014, 8-9).

In 2009 Council (ie. The EU ministers with responsibility for finance and the economy) decided that has occurred an excessive deficit in Poland. Then has recommended, that this be corrected to below 3\% of GDP by 2012 at the latest, inter alia by reducing the structural deficit (ie. the fiscal effort) of at least $1 \frac{1}{4}$ point percent of GDP on average over the period 2010-12. 
The estimates presented in the program in April 2013 showed that the nominal deficit of the general government fell in 2012 to 3.9\% of GDP (compared to $5 \%$ of GDP in 2011). At the same time he was about 1 percentage point. GDP worse than assumed in the Programme of 2012. Decisive influence on the failure to meet the budget had a clear economic downturn in the external environment of Poland and the slowdown in economic growth in the country. As a result, the income of the sector in 2012 turned out to be much smaller than planned. Stability and Growth Pact requires from Member country under the procedure to an excessive deficit to submit to the EU institutions and to publish reports on the actions taken in connection with the recommendations of the Ecofin Council. In a report from October 2013 Poland has estimated that the nominal deficit will increase in 2013 despite the consolidation measures, to $4.8 \%$ of GDP. It was stressed that the increase in the deficit stems almost entirely from the deterioration of cyclical conditions of economy. Taking into account the impact of fiscal consolidation on economic growth, it was considered that the reduction of the deficit in 2013 according to the recommendations of the Ecofin Council level to $3.6 \%$ of GDP, it would be highly pro-cyclical: jeopardize the prospects for economic growth and would create a substantial risk of a recession, even deeper collapse in tax revenues and further increase the deficit. At the same time, in order to reduce the growth of the deficit, was to limit spending growth of $0.5 \%$ of GDP. Given these circumstances, the Commission considered it necessary to set a deadline to correct the excessive deficit. As a result, the Ecofin Council adopted on 10 December 2013 further recommendations for Polish, moving the deadline to liquidate the excessive deficit by 2015 . Based on the new recommendations were formulated targets for the Polish budget for the period 2013-15 - level of nominal deficits, respectively, $4.8 \%$ of GDP, $3.9 \%$ of GDP and $2.8 \%$ of GDP (excluding the impact of the transfer of assets from pension funds to the Social Insurance Fund). The Ecofin Council also said that the achievement of budgetary targets needs a improvement in the structural balance (ie this part of nominal deficit, for which the government has a direct impact) by 1\% of GDP in 2014 and 1.2\% of GDP in the next year.

The Ecofin Council also recommended for the Poland (Informacja o działaniach 2014, Monitor konwergencji 2015):

- improve the quality of public finances,

- improve tax compliance, and the efficiency of tax administration. 
Table 1. Revenue and expenditure and the result of the general government in Poland as\% of GDP in 2004-2013

\begin{tabular}{|l|c|c|c|c|c|c|c|c|c|c|}
\hline \hline & $\mathbf{2 0 0 4}$ & $\mathbf{2 0 0 5}$ & $\mathbf{2 0 0 6}$ & $\mathbf{2 0 0 7}$ & $\mathbf{2 0 0 8}$ & $\mathbf{2 0 0 9}$ & $\mathbf{2 0 1 0}$ & $\mathbf{2 0 1 1}$ & $\mathbf{2 0 1 2}$ & $\mathbf{2 0 1 3}$ \\
\hline \hline Revenue & 37,2 & 39,4 & 40,2 & 40,5 & 39,5 & 37,2 & 37,5 & 38,4 & 38,3 & 37,5 \\
\hline Expenditure & 42,6 & 43,4 & 43,9 & 42,2 & 43,2 & 44,6 & 45,4 & 43,4 & 42,2 & 41,9 \\
\hline Deficit & $-5,4$ & $-4,1$ & $-3,6$ & $-1,9$ & $-3,7$ & $-7,4$ & 7,9 & $-5,0$ & $-3,9$ & $-4,3$ \\
\hline \hline
\end{tabular}

S o u r c e : Eurostat, Convergence report (2012).

Consolidation actions of government led, in the years $2010-13$, to cut spending by 2.8 points. percent. GDP. The expenses after eliminating the funds from the European Union, have been reduced by up to 3.2 points percent GDP. This scale of spending cuts, was possible among others thanks to (Wieloletni plan 2014, 20-21):

- disciplinary rule, in force since 2011, limiting discretionary expenditure growth and new fixed expenditure to $1 \%$ per annum in real terms in 2013. This rule has been replaced by a stabilizing expenditure rule;

- limitation (since 2011) wage fund in the state budget entities through the adoption of the general principle of it is frozen at the nominal level of the previous year;

- periodically (at a time when Poland is subject to an excessive deficit procedure) ban on adoption by government the bills, which may result in loss of income of public sector entities in relation to the size of the applicable in regulations and projects resulting in increased spending;

- currently in force - modified in 2009 - fiscal rules for local governments on debt limits;

- limiting the privileges entitling to early retirement;

- reduced, from 2011, a height of funeral allowance;

- the introduction of income criteria for the receipt of one-off grants for childbirth.

On the other hand, on the revenue side the most important structural measures were (Wieloletni plan 2014, 20-21):

- restriction, from May 2011, part of the pension insurance contributions transferred to OPF from $7.3 \%$ to $2.3 \%$ measurement basis;

- increase in VAT from $22 \%$ to $23 \%$ and from $7 \%$ to $8 \%$, while reducing from $7 \%$ to $5 \%$ for basic food products (January 2011); 
- increase in pension contributions, which be charged the employer by 2 points percent (February 2012);

- limiting the deductibility of VAT paid on the purchase of passenger cars with LCV homologation and fuel used to propel them (from the beginning of 2011);

- increase in excise duty on diesel and fuel charge (from January 2012);

- increase the excise tax on cigarettes (annually since 2010);

- the abolition of tax relief for bio-components in the excise duty (since May 2011);

- maintenance at the nominal level of 2009. tax brackets and lump-sum costs of revenues in the PIT;

- changes in the tax on profits from bank deposits to limit the ability to avoid this tax (introduced in 2012);

- introduction of charges for the use of some resources natural resources (mining tax on copper and silver from April 2012);

- change in the VAT rate on not universal postal services provided by the public operator, to 23\% (April 2013).

Despite the many and significant structural measures, the general government sector revenue, in the years $2010-13$, increased by only 0.4 points percent GDP and after eliminating the income from the European Union budget fell by 0.1 points percent. This was mainly due to weak domestic demand, unfavorable public finance structure of economic growth, very low inflation, and - most importantly - the pro-cyclicality of tax revenue. Negative impact on revenue sector also had problems complying with tax laws. As a result, in 2013 was a slowdown in the pace of fiscal consolidation. While the headline deficit in 2011 has been reduced by 2.8 points percent GDP, and a year later by a further 1.2 percentage point of GDP. In 2013 deficit increased and reached 4.3\% of GDP, ie. by 0.4 percentage points more than in 2012. The effect of changes in income and expenditure on the general government balance present figure 1. 
Figure 1. Effect of changes in income and expenditure on the general government balance in relation to GDP (in percentage points)

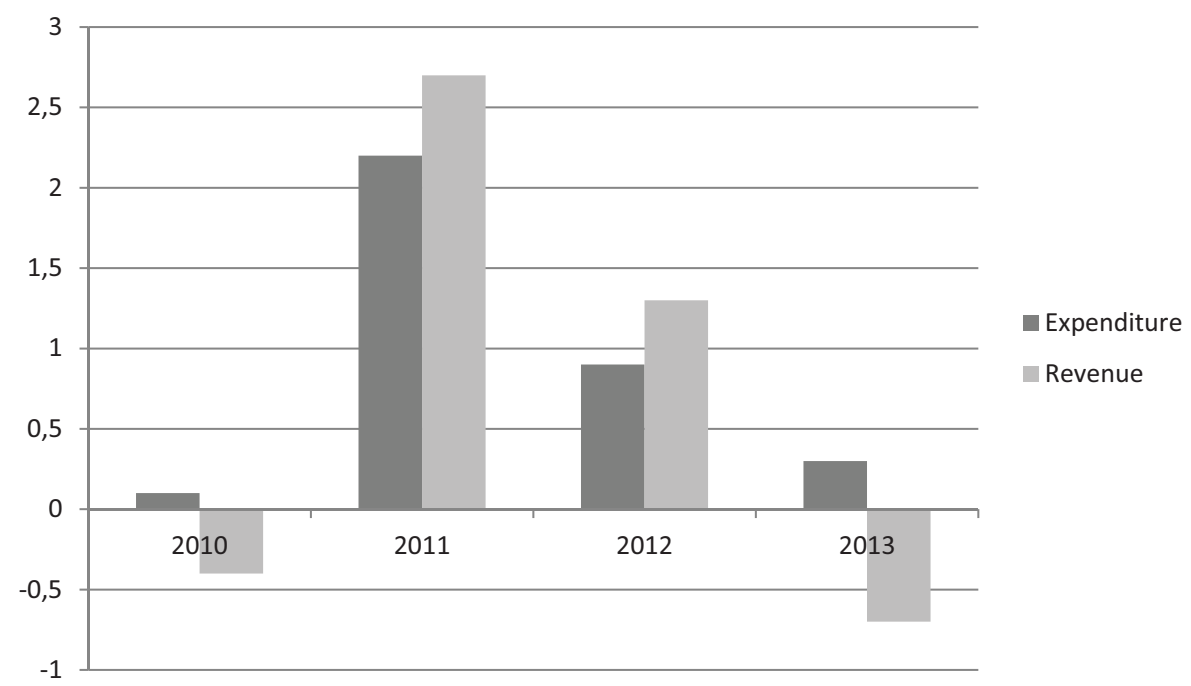

S o u r c e : Ministry of Finance (2015), www.mf.gov.pl.

\section{THE ECOFIN COUNCIL RECOMMENDATIONS FOR POLAND AND CONCLUSIONS}

In December 2013, due to the deteriorating fiscal situation, the ECOFIN Council adopted new recommendations for Poland in the excessive deficit procedure. Deadline for reduction the excessive deficit has been postponed for 2015. Under the new recommendations, Poland should reduce the deficit to $3.9 \%$ of GDP in 2014 and then to 2,8\% of GDP in 2015 excluding the impact of the transfer of pension fund assets. The Ecofin Council has assessed that the achievement of budgetary targets needs for improvement in the structural balance by $1 \%$ of GDP in 2014 and 1.2\% of GDP in the next year (Figure 3). 
Figure 2. Polish structural deficit as\% of GDP

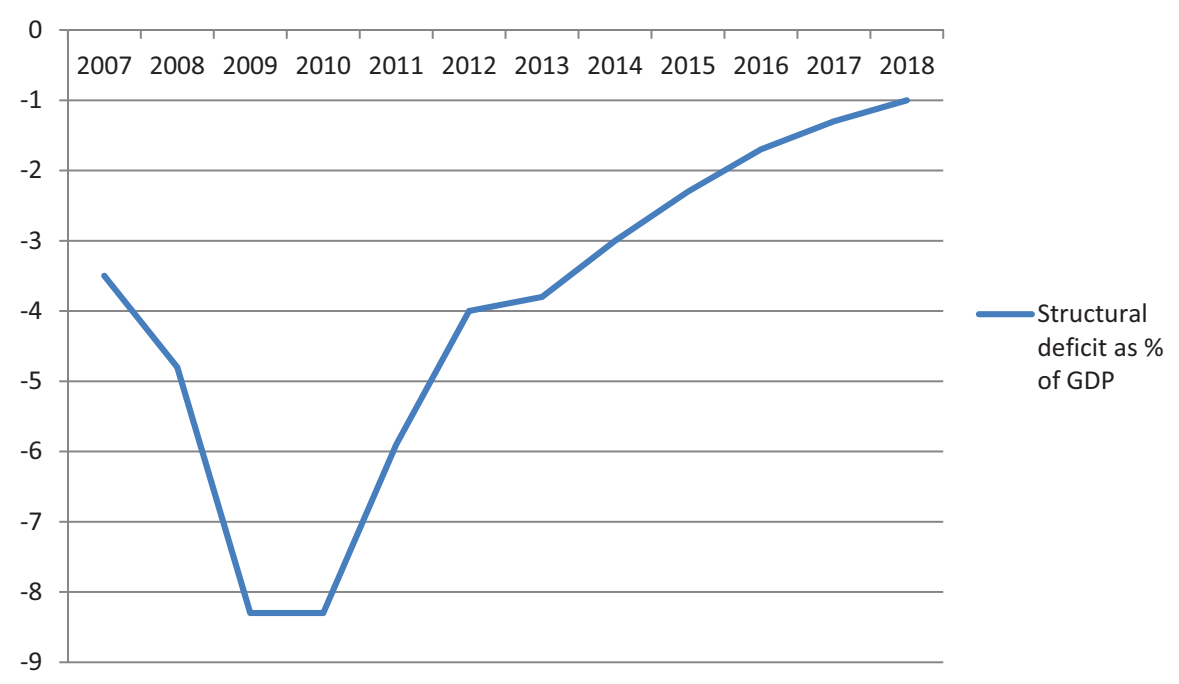

S o u r c e: Ministry of Finance (2015), www.mf.gov.pl.

Poland, according of the recommendations of the council of the EU, in order to reduce the deficit below the reference value (Figures 2 and 3) and keep it at this level decided in 2014-2017:

1) excise tax:

- increase in excise duty on cigarettes (from the beginning of 2014);

- increase in excise duty on ethyl alcohol (from the beginning of 2014);

2) VAT:

- maintaining higher VAT rates unchanged - all originally planned reduction in VAT rates since the beginning of 2014 by 1 point per cent, the reduction in VAT rates by 1 percentage point will take place in 2017;

- limiting the possibility of obtaining reimbursement of VAT on certain expenditure incurred for housing purposes (Law on State aid in the purchase of a first home for young people);

- the introduction of the mini one-stop-shop system from 2014 - change will be to change the place of supply of services in relation to telecommunications, broadcasting, radio and television broadcasting and electronically supplied services to non-taxable persons; 
3) CIT:

- introduction of taxation of companies limited by shares;

- exclusion of the right to exemption from corporate income tax payments of dividends and other income (revenue) from a share in profits of legal persons deductible in the company paying and the method of determining the income of benefits in kind (since 2015);

4) from 2016, will be introduced new system of payments to the central budget from the State Forests. It will be $2 \%$ revenue obtained by the $\mathrm{Na}$ tional Forests from timber sales;

5) withdrawal from the implementation of a mechanism enabling taxpayers of corporate income tax to transmission of $1 \%$ of tax for research units - in accordance with the decision of the Council of Ministers, these issues will depend on the state of public finances.

Figure 3. General government deficit as \%of GDP

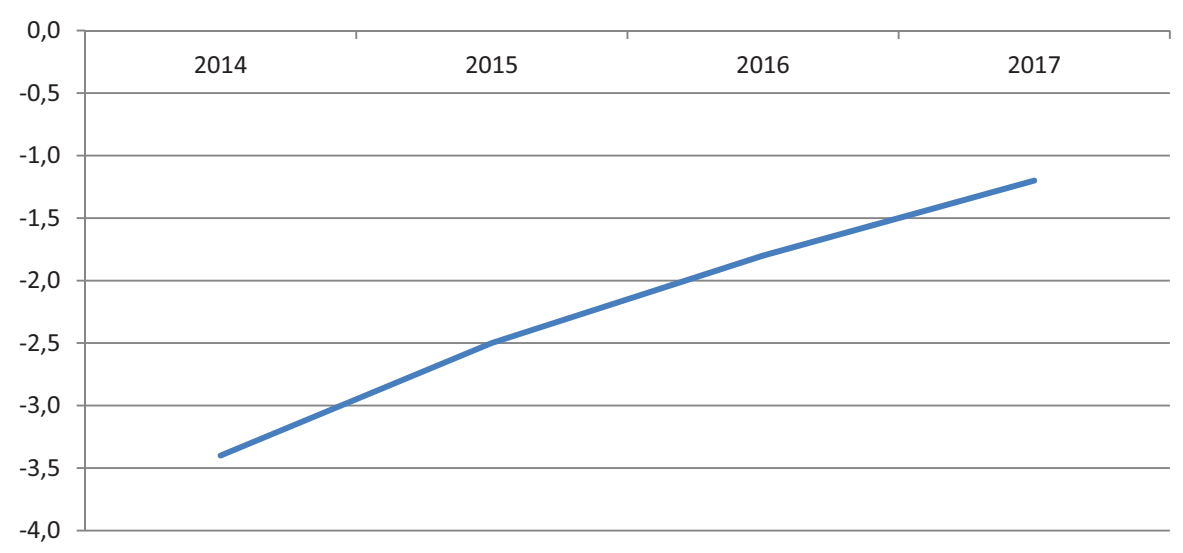

S o u r c e : Ministry of Finance (2015), www.mf.gov.pl. 
Figure 3. Effect of changes in income and expenditure on the general government balance in relation to GDP (in percentage points)

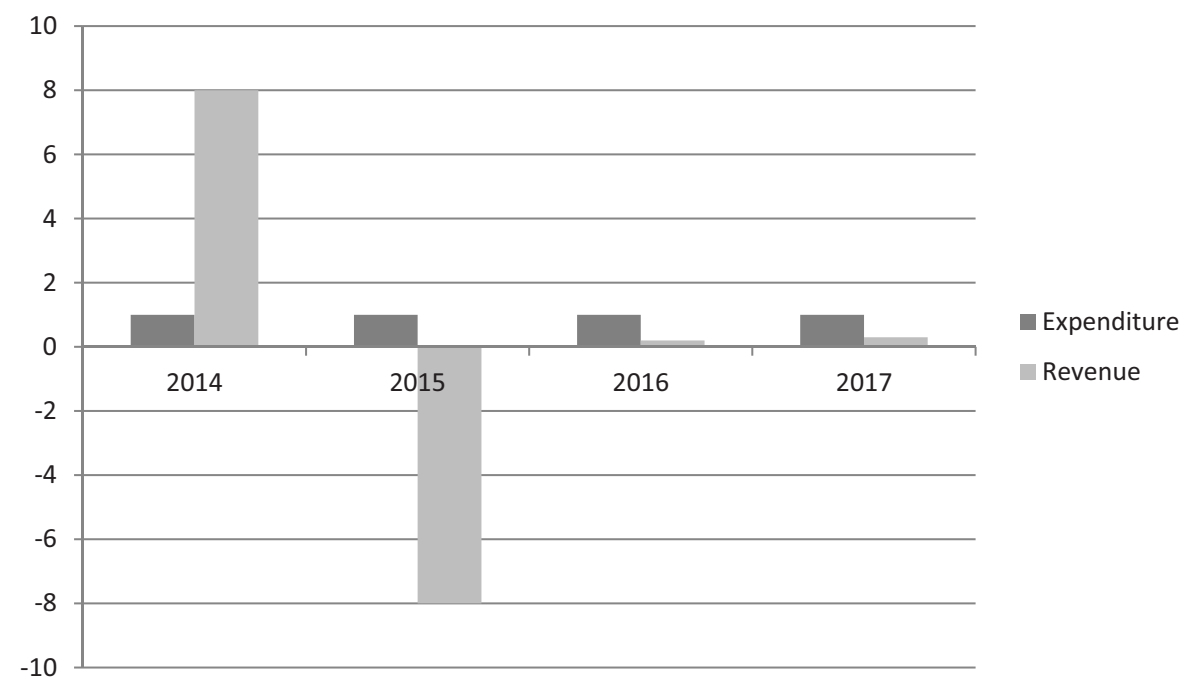

S o u r c e : Ministry of Finance (2015), www.mf.gov.pl.

In addition, government are working on:

- introduction of contributions of civil contracts, in particular service contracts and the introduction of pension contributions of members of supervisory boards;

- increasing of the productivity of tax administration.

In contrast, on the expenditure side are mainly taken action affecting the level of social expenditure and current expenditure, among others:

- liquidation of preference rules for calculating the salaries of uniformed officers and soldiers, as well as members of the judiciary (judges and prosecutors) in the course of the disease;

- reforming the rules for determining the base of sickness benefit if the insurance period is less than 12 months - these changes relate to persons engaged in non-agricultural business and other groups of people for whom the contribution basis is the amount declared;

- esignation - the decision of the Council of Ministers - of introducing the rector scholarship for the best students in the first year of study;

- the works on electronic system of sick leave - the implementation of system will reduce the cost of printing letterheads, enable a faster control 
on the regularity of the use of sick leave and the regularity of ruling on temporary incapacity to work.

The effect of changes in income and expenditure on the general government balance in relation to GDP presents figure 3.

According to the information and forecast presented in this study, the deficit in 2015 will decrease to $2.5 \%$ of GDP, below the level recommended by the Council $-2.8 \%$ of GDP. Also in 2014 the general government deficit stood at $3.3 \%$ of GDP and was 0.6 points percent lower than the recommended Council.

The government is determined to limit the imbalance of public finances in the medium term without jeopardizing the development prospects of of the country. The next years will be so focused on the achievement by the Poland in 2018. Medium-term objective (MTO), which is a structural deficit of $1 \%$ of GDP. Realization of MTO will ensure the achieving and maintaining debt of the general government significantly below the reference value of $60 \%$ of GDP.

\section{REFERENCES}

Borsi M. Metiu N. (2013), The evolution of economic convergence in the European Union, Deutsche Bundesbank Discussion Paper.

Ciak J. (2012), Źródła finansowania deficytu budżetu państwa w Polsce, CeDeWu.pl, Warszawa.

Convergence report (2012), European commission.

Ekonomiczne wyzwania integracji Polski ze strefą euro (2014), NBP, Warszawa.

Eurostat datebase 2013.

Fiscal compact signed: Strengthened fiscal discipline and convergence in the euro area Brussels, 2 March 2012, http://www.consilium.europa.eu/Newsroom (accessed: 30.03.2015).

Hallerberg M., Strauch R., von Hagen J. (2007). The design of fiscal rules and forms of governance in European Union countries. European Journal of Political Economy, 23(2), 338-359. http://dx.doi.org/10.1016/j.ejpoleco.2006.11.005 .

Harden I., J. von Hagen (1995). Budget Processes and Commitment to Fiscal Discipline. European Economic Review, 39(3), 771-779. http://dx.doi.org/10.1016/0014-2921(94)00084-d.

Informacja o działaniach podjętych przez Polskę w celu realizacji rekomendacji rady w ramach procedury nadmiernego deficytu (2014), Warszawa.

Houben A., Kakes J. (2013). Financial imbalances and macroprudential policy in a currency union. DNB Occasional Study, 11(5).

Kasperowicz-Stępień A. (2013), Problem bankructwa państwa, Zeszyty Naukowe Uniwersytetu Ekonomicznego w Krakowie, Kraków. 
Kasperowicz-Stępień A. (2011), Działania Eurosystemu na rzecz zapewnienia stabilności finansowej, Zeszyty Naukowe Uniwersytetu Ekonomicznego w Krakowie, Kraków.

Kryzys finansów publicznych (2013), Oręziak L. Rosati D. (ed.), Wydawnictwo Łazarski, Warszawa.

Ministerstwo Finansów (2014). Implikacje reformy instytucjonalnej strefy euro dla procesu wprowadzenia eurow Polsce. Euroopracownia, nr 14.

Monitor Konwergencji Nominalnej (2015), Rada Ministrów, Warszawa.

Monitor Konwergencji Realnej (2015), Rada Ministrów, Warszawa.

Ochrymiuk M. (2010), Konwergencja nominalna w strefie euro. Implikacje dla Polski, NBP, Warszawa.

Oręziak L. (2004), Finanse Unii Europejskiej, Wydawnictwo Naukowe PWN, Warszawa.

Owsiak St. (2005), Finanse publiczne. Teoria i praktyka, Wydawnictwo Naukowe PWN, Warszawa.

Rada Ministrów (2014), Wieloletni plan finansowy państwa na lata 2014-2017, Warszawa.

Sektor finansów publicznych w warunkach światowego kryzysu finansowego (2011), Alińska A. (ed.), CeDeWu.pl, Warszawa.

Stefański R. (2008). Synchronizacja cyklu koniunkturalnego a realna konwergencja Polski ze strefą euro. Ruch Prawniczy Ekonomiczny i Socjologiczny, nr 4.

Wernik A. (2014), Finanse publiczne, Polskie Wydawnictwo Ekonomiczne, Warszawa.

Wyplosz Ch. (2013). Europe's Quest for Fiscal Discipline. European Economy. Economic Paper, 498, April.

Vamvakidis A. (2008), Convergence in Emerging Europe: Sustainability and Vulnerabilities, IMF Working Paper. 